University of Nebraska - Lincoln

DigitalCommons@University of Nebraska - Lincoln

2011

Statistical Distribution of Streambed Vertical Hydraulic

Conductivity along the Platte River, Nebraska

\author{
Cheng Cheng \\ University of Nebraska-Lincoln \\ Jinxi Song \\ Northwest University, Xi'an, China \\ Xunhong Chen \\ University of Nebraska - Lincoln, xchen2@unl.edu \\ Deming Wang \\ University of Nebraska-Lincoln
}

Follow this and additional works at: https://digitalcommons.unl.edu/natrespapers

Cheng, Cheng; Song, Jinxi; Chen, Xunhong; and Wang, Deming, "Statistical Distribution of Streambed Vertical Hydraulic Conductivity along the Platte River, Nebraska" (2011). Papers in Natural Resources. 362.

https://digitalcommons.unl.edu/natrespapers/362

This Article is brought to you for free and open access by the Natural Resources, School of at DigitalCommons@University of Nebraska - Lincoln. It has been accepted for inclusion in Papers in Natural Resources by an authorized administrator of DigitalCommons@University of Nebraska - Lincoln. 


\title{
Statistical Distribution of Streambed Vertical Hydraulic Conductivity along the Platte River, Nebraska
}

\author{
Cheng Cheng, ${ }^{1}$ Jinxi Song, ${ }^{1,2}$ Xunhong Chen, ${ }^{1}$ and Deming Wang ${ }^{1}$
}

1. School of Natural Resources, University of Nebraska-Lincoln, Lincoln, NE 68583-0996, USA

2. College of Urban and Environmental Sciences, Northwest University, Xi'an, 710127, China

Corresponding author - Xunhong Chen, email xchen2@unl.edu

\begin{abstract}
Streambed vertical hydraulic conductivity $\left(K_{v}\right)$ plays an important role in understanding and quantifying the stream-aquifer interactions. While several researchers have discussed the spatial variability of streambed horizontal hydraulic conductivity or $K_{v}$ at one or several close-located sites in a river, they did not develop any statistical distribution analysis of streambed $K_{v}$ at distant sites along a large river. In this paper, the statistical distribution and spatial variation of streambed $K_{v}$ at 18 test sites in a $300-\mathrm{km}$ reach of the Platte River in Nebraska are presented. Insitu permeameter tests using the falling-head method were carried out to calculate the streambed $K_{v}$ values. Fine-grained sediments transported by two tributaries, the Loup River and the Elkhorn River, to the Platte River appear to result in lower streambed $K_{v}$ values downstream of the confluences between the Platte River and the tributaries. The streambed $K_{v}$ values were found to be normally distributed at nearly each test site. When the correlated $K_{v}$ values were eliminated from the grid sampling plots, the remaining independent sub-datasets of streambed $K_{v}$ values were still in normal distribution at each test site. Furthermore, the combined streambed $K_{v}$ values upstream of the first confluence between the Platte River and the Loup River was normally distributed, which may be due to the lack of tributaries in-between and thus streambed sediments were well distributed in this reach and belonged to a single population of hydraulic conductivity values. In contrast, the combined dataset of all measurements conducted downstream of this confluence was no longer in normal distribution, presumably as a result of the mixing of different sediment sources.
\end{abstract}

Keywords: streambed vertical hydraulic conductivity, permeameter test, normal distribution, Platte River 


\section{Introduction}

Streambed vertical hydraulic conductivity $\left(K_{v}\right)$ plays an important role in understanding and quantifying the stream-aquifer interactions and stream ecosystems (Goswami et al. 2010). Chen and Shu (2002) reported that a higher streambed $K_{v}$ induces a higher rate of stream depletion due to groundwater withdrawal. Sun and Zhan (2007) noted that one of the most important factors controlling the interaction of an aquifer with two parallel streams is the hydraulic conductivity ratio of the two streambeds, especially when a low-K streambed exists. Heterogeneity of streambed $K$ could affect hyporheic zone fluxes and groundwater discharge (Salehin et al. 2004; Kalbus et al. 2009; Kennedy et al. 2009). Also, hyporheic exchange at channel surface affects the distribution of streambed $K_{v}$ such that streambed $K_{v}$ in the upper sediment layer is higher than that in the lower sediment layer (Song et al. 2007). Therefore, knowledge of streambed $K_{v}$ is essential to characterize hydrologic connections between a stream and its adjacent aquifers, and streambed $K_{v}$ is also a necessary parameter in numerical modeling of stream-aquifer interactions (Sophocleous et al. 1995).

A number of researchers discussed the methods for the determination of streambed K, which include the permeameter test (Hvorslev 1951; Chen 2000, 2004, 2005; Landon et al. 2001; Genereux et al. 2008; Kennedy et al. 2009), slug and bail tests (Springer et al. 1999; Landon et al. 2001; Ryan and Boufadel 2007; Leek et al. 2009), grain-size analysis (Chen 2000; Landon et al. 2001), and pumping test (Kelly and Murdoch 2003). Generally slug and bail tests can only provide streambed horizontal hydraulic conductivity $\left(K_{\mathrm{h}}\right)$ values, while grain-size analysis cannot evaluate the anisotropy of $K$ values because the sediment structure is destroyed during sampling (Chen 2000; Kalbus et al. 2006; Cheng and Chen 2007). In contrast, permeameter tests can provide streambed $K_{v}$ values which are more accurate than grain-size analysis and less expensive than those determined using pumping tests. The spatial and temporal variations of streambed $K_{\mathrm{h}}$ and $K_{v}$ have been analyzed and discussed by many researchers. Springer et al. (1999) suggested a bimodal distribution for the $K_{\mathrm{h}}$ of the sediments within several reattachment bars in the Colorado River of Grand Canyon. They also noted that $K_{\mathrm{h}}$ is lower after a flood due to the increased effective stress of the newly deposited sediments. Cardenas and Zlotnik (2003) used multilevel constant-head injection tests to collect streambed $K_{\mathrm{h}}$ values in the Prairie Creek of Nebraska, and their results indicated that streambed $K_{\mathrm{h}}$ is normally distributed based on 456 measurements. Chen (2005) performed 124 in situ permeameter tests at eight sites along the Platte River in south-central and eastern Nebraska. He found that streambed $K_{v}$ values of the Platte River show a normal distribution when $48 K_{v}$ values from one test site in eastern Nebraska were excluded. Ryan and Boufadel (2007) conducted slug tests using a portable fallinghead permeameter to estimate streambed $K_{\mathrm{h}}$ values at two different depths in the Indian Creek in Philadelphia, Pennsylvania. They noted that $K_{\mathrm{h}}$ is log-normally distributed within each sediment layer but not for the combined dataset of two sediment layers. Additionally, their results indicated that streambed $K_{\mathrm{h}}$ decreases with depth while horizontal heterogeneity increases with depth. Genereux et al. (2008) carried out in situ permeameter tests to obtain 487 measurements of streambed $K_{v}$ over the course of a year in the West Bear 
Creek in North Carolina. They found that streambed $K_{v}$ values are neither normally nor log-normally distributed, but are found to have a bimodal distribution. Moreover, their results indicated that streambed $K_{v}$ varies spatially in a river, and the highest $K_{v}$ appears in the center of the channel which may be due to the differences of streambed sediment grain size between the center and the sides of the channel. They also pointed out that erosion and deposition may contribute to the observed temporal variation of streambed $K_{v}$.

The hydraulic conductivity of aquifer materials has most often been found to be log-normally distributed (Freeze 1975; Bjerg et al. 1992; Hess et al. 1992; Sudicky 1986; Woodbury and Sudicky 1991; Rehfeldt et al. 1992). Chen et al. (2008) used Geoprobe direct-push techniques to generate the electrical conductivity (EC) logs and collect cores of channel sediments at nine sites from Kearney to Columbus in the Platte River. Their results indicated that the streambed near the channel surface at these sites consists mostly of sand and gravel. For the area studied, there was no apparent boundary between channel sediments and the underlain alluvial aquifer; thus, streambed sediments in this reach of the Platte River may be considered part of the aquifer material (Chen et al. 2008). Above all, the $K_{v}$ value of streambed near the channel surface is a crucial factor in controlling the interactions between surface water and groundwater, and it is beneficial to better understand its statistical distribution and spatial variability at different sites in a large river.

Over the past 10 years, numerous in situ and laboratory permeameter tests have been conducted in determining streambed $K_{v}$ in the Platte River of Nebraska (Landon et al. 2001; Chen 2004, 2005; Song et al. 2007; Chen et al. 2008). Landon et al. (2001) performed in situ permeameter tests to investigate the streambed $K_{v}$ in the Platte River near Brady. They concluded that streambed $K_{v}$ is usually greater than $50 \mathrm{~m} /$ day; however, their results were based on the top 25-cm streambed. Chen (2004) presented the streambed $K_{v}$ values in three rivers (the Platte, Republican, and Little Blue Rivers) in south-central Nebraska. The average $K_{v}$ ranges from 15 to $47 \mathrm{~m} /$ day with an $L_{v}$ (length of sediments in the tube) of $40 \mathrm{~cm}$ for sandy streambed. The average streambed $K_{v}$ is $40.2 \mathrm{~m} /$ day at seven test sites between Kearney and Central City in the Platte River (Chen 2005). Song et al. (2007) reported that the average streambed $K_{v}$ is about 34.4 and $48.2 \mathrm{~m} /$ day for sites F and G (see Figure 1 for site locations) in the Platte River.

Most of the previous research papers discussed the spatial variability of streambed $K_{\mathrm{h}}$ or $K_{v}$ at one or several adjacent sites in small creeks (Cardenas and Zlotnik 2003; Ryan and Boufadel 2007; Genereux et al. 2008); however, they did not develop a statistical distribution analysis of streambed $K_{v}$ at distant sites along a large river. Although Chen (2005) analyzed the streambed $K_{v}$ values at eight sites in the Platte River, he did not provide site-by-site statistical distribution analysis of streambed $K_{v}$ values in the Platte River in Nebraska, and the test sites in his study were mainly located in the reach without tributaries to the Platte River. Furthermore, additional streambed $K_{v}$ measurements were conducted at two other sites in the Platte River (Song et al. 2007) and at eight new test sites in this study. The objective of this paper is to determine the statistical distribution and spatial variation of streambed $K_{v}$ values at 18 test sites between Kearney and Ashland, about $300 \mathrm{~km}$ apart, in the Platte 


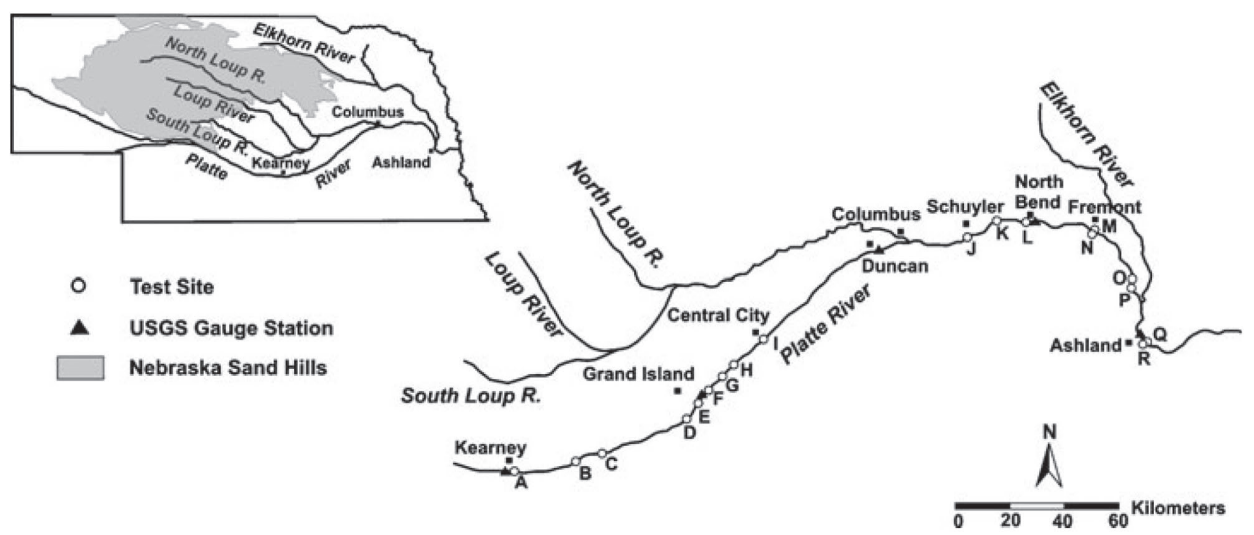

Figure 1. Map showing the study sites. In situ permeameter tests were performed at 18 test sites (from sites a to q) between Kearney and Ashland, square dots indicating the nearby city or town names.

River from south-central to eastern Nebraska (Figure 1). This study can provide a detailed picture of site-by-site statistical distribution of streambed $K_{v}$ along a $300-\mathrm{km}$ segment of the Platte River, and present the possible influences of tributary in controlling streambed permeability at a large scale.

\section{Study Area and Test Sites}

The study sites are located in the Platte River from south-central to eastern Nebraska (Figure 1). The Platte River originates from the Rocky Mountains and flows through Nebraska from west to east. Within Nebraska, the Platte River is braided at some locations and the Loup River and the Elkhorn River merge with the Platte River in eastern Nebraska. The primary land uses in the basin consist of dry cropland, irrigated cropland, pastureland, and rangeland. Dense vegetation including trees, shrubs and grasses occur in the riparian zone, and cottonwood is the dominant tree. Data from a climate station near Fremont showed the average annual precipitation was about $755 \mathrm{~mm}$ between 1950 and 2004. The monthly precipitation shows that most of the precipitation occurs from April to September, which accounts for $75 \%$ of the total annual amount. The Platte River is usually wider than $200 \mathrm{~m}$, becomes wider toward downstream and can be as wide as $400 \mathrm{~m}$ at Ashland. However, the Platte River is generally shallow and the water depth is less than $1 \mathrm{~m}$ (Chen et al. 2008). The Platte River is an important habitat for a number of endangered river species. In recent years, stream depletion in the Platte River due to extensive use of groundwater has become an important issue because it may threaten river habitats (Chen and Shu 2002; Chen 2007).

Five USGS (U.S. Geological Survey) gauge stations recorded the stream stage and streamflow rate in the Platte River within the study area. The stations are USGS 06770200 near Kearney, USGS 06770500 near Grand Island, USGS 06774000 near Duncan, USGS 06796000 near North Bend, and USGS 06801000 near Ashland, respectively (Figure 1). The average stream level and stream discharge for the five stations are shown in Table 1. Thus, the Platte River may bring fine-grained sediments from up- 
Table 1. Average stream level and stream discharge of the Platte River at five USGS gauge stations

\begin{tabular}{llllll}
\hline $\begin{array}{l}\text { Station } \\
\text { location }\end{array}$ & $\begin{array}{l}\text { USGS } \\
\text { code }\end{array}$ & $\begin{array}{l}\text { Mean stream } \\
\text { level }(\mathrm{m})\end{array}$ & $\begin{array}{l}\text { Stream level } \\
\text { date range }\end{array}$ & $\begin{array}{l}\text { Mean stream } \\
\text { discharge }\left(\mathrm{m}^{3} / \mathrm{s}\right)\end{array}$ & $\begin{array}{l}\text { Discharge } \\
\text { date range }\end{array}$ \\
\hline Kearney & 06770200 & 651 & 1987 to 2008 & 38 & 1985 to 2008 \\
Grand Island & 06770500 & 559 & 1986 to 2008 & 44 & 1942 to 2008 \\
$\begin{array}{l}\text { Duncan } \\
\text { North Bend }\end{array}$ & 06774000 & 451 & 1997 to 2008 & 50 & 1941 to 2008 \\
Ashland & 06801000 & 386 & 1989 to 2008 & 128 & 1949 to 2008 \\
\hline
\end{tabular}

stream stations to downstream stations and result in a downstream fining trend. Furthermore, the higher streamflow discharge rate at the North Bend and Ashland stations is a result of the contribution of streamflow from the Loup River and the Elkhorn River.

Streambed $K_{v}$ values at 10 of the 18 sites between Kearney and Ashland in the Platte River were presented by Chen $(2004,2005)$, and Song et al. (2007). Eight new test sites between Schuyler and Ashland (Figure 1), about $100 \mathrm{~km}$ apart along the Platte River in eastern Nebraska, were selected to perform permeameter tests in June and July 2008. The total eighteen sites were designated as sites A to R between Kearney and Ashland in the Platte River (Figure 1). At each site, tens to hundreds of measurements of in situ permeameter tests were made to characterize the streambed variability. Near the City of Fremont, two test sites were selected. One was site $\mathrm{M}$ where the permeameter tests were conducted close to the north bank of the Platte River, and the other one was site $\mathrm{N}$ where the permeameter tests were conducted near the south bank of the Platte River. Similarly, near the City of Ashland, the tests conducted at site $Q$ in this study were located in the eastern half of the Platte River, while the tests at site R conducted by Chen (2005) were located in the western half of the river. Most of the permeameter tests were conducted in sandy streambed sediments and were over $50 \mathrm{~m}$ away from the river bank. However, at site $\mathrm{M}$, the nearest measurements were only $3.0 \mathrm{~m}$ from the river bank.

\section{Methods}

\subsection{In situ Permeameter Test}

An in situ permeameter test using the falling head method usually involves inserting a standpipe into channel sediments (Figure 2). In this case, transparent polycarbonate tubes were used for all the tests. The tube is $147 \mathrm{~cm}$ in length and $5.1 \mathrm{~cm}$ in diameter, and is pressed vertically into the channel sediments. The wall of the tube is about $1 \mathrm{~mm}$ thick, thus its effects of disturbance on streambed sediments would be expected to be negligible. After the tube was pressed into a desired depth, the tube remained in the channel for an appropriate length of time to allow the hydraulic head inside the tube to reach equilibrium due to the slight compaction of the streambed sediments inside the tube (Chen et al. 2009). After the head inside the tube equilibrated, the surface water-level at the streambed surface was considered as the initial hydraulic head at the measurement point. Water was then added from the top of the tube. The hydraulic head in the tube began to fall and the head was recorded in 
Figure 2. Schematic diagram showing in situ permeameter test to determine streambed $\mathrm{Kv}$ (Chen 2000).

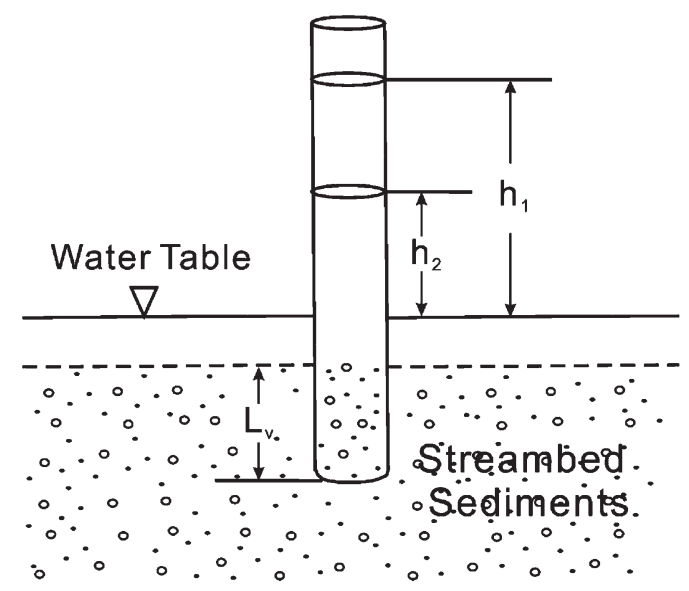

different time steps. In the study, water levels were recorded more than 10 times for each permeameter test. Any pair of measurements from the in situ permeameter tests can be used to calculate the $K_{v}$ value using the equation of Hvorslev (1951):

$$
K_{v}=\frac{\frac{\pi D}{11 m}+L_{v}}{\left(t_{2}-t_{1}\right)} \ln \left(h_{1} / h_{2}\right)
$$

where $L_{v}$ is the length of sediment in the tube; $h_{1}$ and $h_{2}$ are hydraulic head inside the tube measured at times $t_{1}$ and $t_{2}$, respectively, $D$ is the interior diameter of the tube, and $m=\sqrt{K_{h} / K_{v} \cdot K_{h}}$ is the horizontal hydraulic conductivity of the channel sediment around the base of the sediment core.

A nonlinear regression method was used to determine the streambed $K_{v}$ (Chen 2005). This method could enhance the estimation of $K_{v}$ by taking into account all the water level records simultaneously. In the computation of $K_{v}$ m must be arbitrarily chosen. Chen (2004) noted that increasing $L_{v}$ could reduce the overestimation of $K_{v}$. He found that the estimation error of $K_{v}$ is less than $5 \%$ by arbitrarily choosing a value of $\mathrm{m}$ when the ratio of $L_{v}$ to $D$ is greater than 5 . All tubes were $5.1 \mathrm{~cm}$ in diameter in this study. The $L_{v}$ for each measurement of in situ permeameter tests ranged from 42 to $58.4 \mathrm{~cm}$. Therefore, the ratios of $L_{v}$ to $D$ are all greater than 5 for the in situ permeameter tests at all sites.

The number of permeameter tests, the grid spacing between test points, the average $L_{v}$, and the average water depth are summarized for each of the eight new test sites (sites J to Q) between Schuyler and Ashland in the Platte River, which are shown in Table 2.

\subsection{Normality Test and $t$-Test}

Normality tests are used to determine whether a set of measurements comes from a normal distribution population. In this study, Jarque-Bera (J-B), KolmogorovSmirnov (K-S), Lilliefors, and Shapiro-Wilk (S-W) tests (Sprent 2001) were applied at the 0.05 significance level. The K-S and S-W tests are commonly used, and the Lil- 


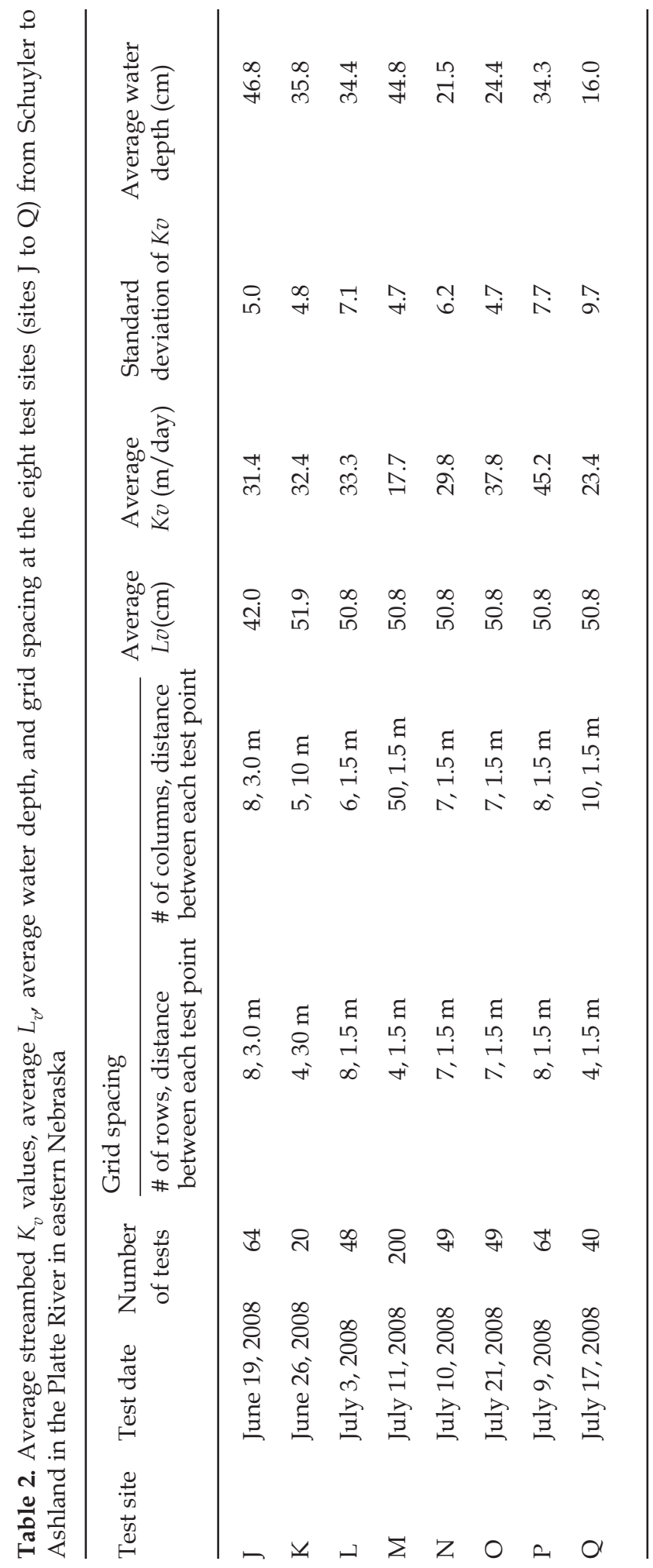


liefors test is an adaption of the K-S test. The S-W test has requirements for the sample size $N(7 \leq N \leq 2,000)$, while the $\mathrm{K}-\mathrm{S}$ and Lilliefors tests are preferable to apply for a large sample size $N(N \geq 2,000)$. The J-B test is not good at distributions with short tails, and the K-S and Lilliefors tests are also less powerful than the $S-W$ test. These tests were used to determine whether streambed $K_{v}$ at each test site is normally distributed. Furthermore, a $t$-test with unequal variance is used to compare the $K_{v}$ values at two test sites, and this test can determine whether streambed $K_{v}$ differ significantly between different test sites.

\subsection{Determination of Independent Samples Using an Exponential Model}

Rehfeldt et al. (1992) noted that a population of samples can be reduced to independent samples by taking out the spatially correlated samples, and they introduced a reduction factor to identify both the horizontal and vertical correlation. In this study, we used an exponential model to fit the experimental semi-variogram along the flow direction at each test site. The fitted model provided the correlation scale (Hess et al. 1992; Genereux et al. 2008; Zhao et al. 2010). If the correlation scale is smaller than the sampling spacing, then the measurements of streambed $K_{v}$ were regarded as independent; otherwise, the measurements within the correlation scale were eliminated from the sample and thus the remaining streambed $K_{v}$ values were considered to be independent. Furthermore, the streambed $K_{v}$ values across the flow direction were regarded as independent in this study. The exponential model used in this study did not include a nugget effect, and is written as

$$
r=C\left(1-\exp \left(\frac{-h}{\lambda}\right)\right)
$$

where $\gamma$ is the semi-variogram statistic, $C$ is the variogram sill value, $h$ is the lag distance, and $\lambda$ is the correlation scale. Note that this correlation scale is related to the range of influence but not the range of influence as defined in some geostatistical text books (Goovaerts 1997). The four normality tests were also used to testify the independent sub-datasets of streambed $K_{v}$ values.

\section{Results}

\subsection{Streambed $K_{v}$ Values Between Schuyler and Ashland in the Platte River}

Previous studies showed that the vertical hydraulic gradient (VHG) may vary spatially across the streambed at nearby locations (Chen et al. 2009; Leek et al. 2009). Chen et al. (2009) noted that the positive and negative VHG values could occur between two locations only several meters apart for the streambed sediments in the Elkhorn River of Nebraska, which indicates the significant presence of downward and upward flux at water-streambed interface. Similar findings were reported by Leek et al. (2009). In this study, the VHG values at the test sites in the Platte River are very small (all less than 0.02), thus using the surface water-level at the streambed surface 
as the initial hydraulic head at the measurement point may not greatly affect the accuracy of the estimation of streambed $K_{v}$ values.

The average streambed $K_{v}$ values and standard deviation of $K_{v}$ at each of the eight new test sites are shown in Table 2. The average $L_{v}$ from sites $\mathrm{J}$ to $\mathrm{Q}$ in this study is about $49.8 \mathrm{~cm}$, which is slightly larger than that from sites A to I and site R $(40.7 \mathrm{~cm})$ from previous studies (Chen 2004, 2005; Song et al. 2007). At sites J, K, and L, the average streambed $K_{v}$ values were similar. The different average streambed $K_{v}$ values at sites $\mathrm{M}$ and $\mathrm{N}$ indicated that $K_{v}$ values can vary significantly in space, even though the two sites are adjacent. Furthermore, the average streambed $K_{v}$ values at the two sites were lower than those values at sites J, K, and L; while the average streambed $K_{v}$ values at sites $\mathrm{O}$ and $\mathrm{P}$ were higher than those values at other test sites.

The test site near Ashland (site Q) in this study was different from the Ashland site (site R) of Chen (2005). He performed in situ permeameter tests along four transects on the west half of the Platte River, while the permeameter tests in this study were conducted on the east half of the Platte River, about $200 \mathrm{~m}$ apart from the test locations of Chen (2005). The streambed $K_{v}$ values ranged from 2.9 to $41.9 \mathrm{~m}$ / day with an average $K_{v}$ of $23.4 \mathrm{~m} /$ day, while Chen (2005) reported that the average streambed $K_{v}$ is $16.8 \mathrm{~m} /$ day at 40 test points. Nevertheless, the standard deviation of streambed $K_{v}$ of the two sites is similar. The average $K_{v}$ value at site $Q$ was lower than those values at other new test sites in this study except for site $M$.

Out of the eight new test sites, the $K_{v}$ values at site $Q$ had the largest standard deviation, while the $K_{v}$ values at siteMhad the smallest standard deviation (Table 2; Figure 5). Large standard deviation of $K_{v}$ indicates that the streambed $K_{v}$ values can vary significantly within the same site, especially at sites J, P, and Q (Table 2). On the whole, the standard deviations of $K_{v}$ values at the eight sites were slightly different, and they were smaller than those from sites A to I between Kearney and Central City in the Platte River (Chen 2004, 2005; Song et al. 2007; Table 3). This difference is probably because (1) a larger number of permeameter tests were conducted at the eight new sites in this study and (2) the tests for these eight new sites were conducted in regularly spaced but closely located points compared to the tests along the acrosschannel transect for the sites A to I between Kearney and Central City (Chen 2004, 2005; Song et al. 2007). It can be anticipated that larger heterogeneity in streambeds exists along a transect across the channel and less heterogeneity in streambeds of smaller scale plots.

\subsection{Statistical Distribution of Streambed $K_{v}$ Values along the Platte River}

The histograms of the streambed $K_{v}$ values and the cumulative distributions on normal probability plots at the eight new sites (sites J to Q) from Schuyler to Ashland in the Platte River are shown in Figure 3(a-h). The J-B and S-W tests indicated that the streambed $K_{v}$ values are in normal distribution at the eight test sites at the 0.05 significance level except for site $\mathrm{N}$ (Table 3), while the Lilliefors and K-S tests implied nonnormal distribution of streambed $K_{v}$ at sites $\mathrm{J}$ and $\mathrm{Q}$ as well as site $\mathrm{N}$. At site N, all four tests suggested that the streambed $K_{v}$ values are not in normal distribution at the 0.05 significance level, since the $p$-values are all smaller than 0.05 . However, if the two 

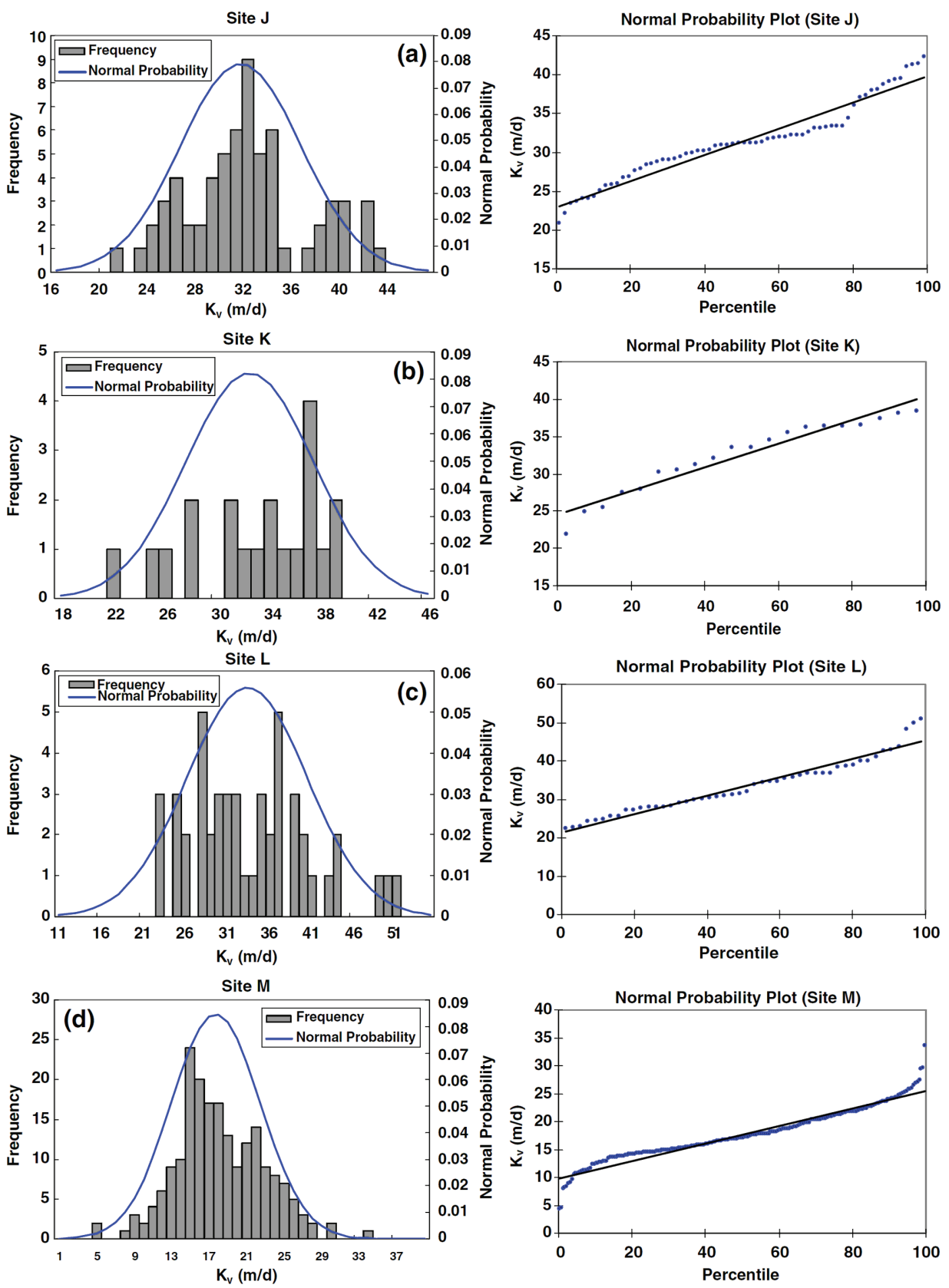

Figure 3. Histograms and normal probability plots of streambed $K v$ from sites $\mathrm{J}$ to $\mathrm{Q}$ between Schuyler and Ashland in the Platte River a site J; $\mathbf{b}$ site K; $\mathbf{c}$ site L; $\mathbf{d}$ site M; e site N; $\mathbf{f}$ site O; $\mathbf{g}$ site P; h site $Q$.

largest $K_{v}$ values were considered as outliers and eliminated from the sample, the remaining $47 K_{v}$ values at site $\mathrm{N}$ were normally distributed from all four normality tests. Furthermore, the 48 streambed $K_{v}$ values at site $R$ determined by Chen (2005) were normally distributed according to the Lilliefors and K-S tests. When the streambed $K_{v}$ val- 

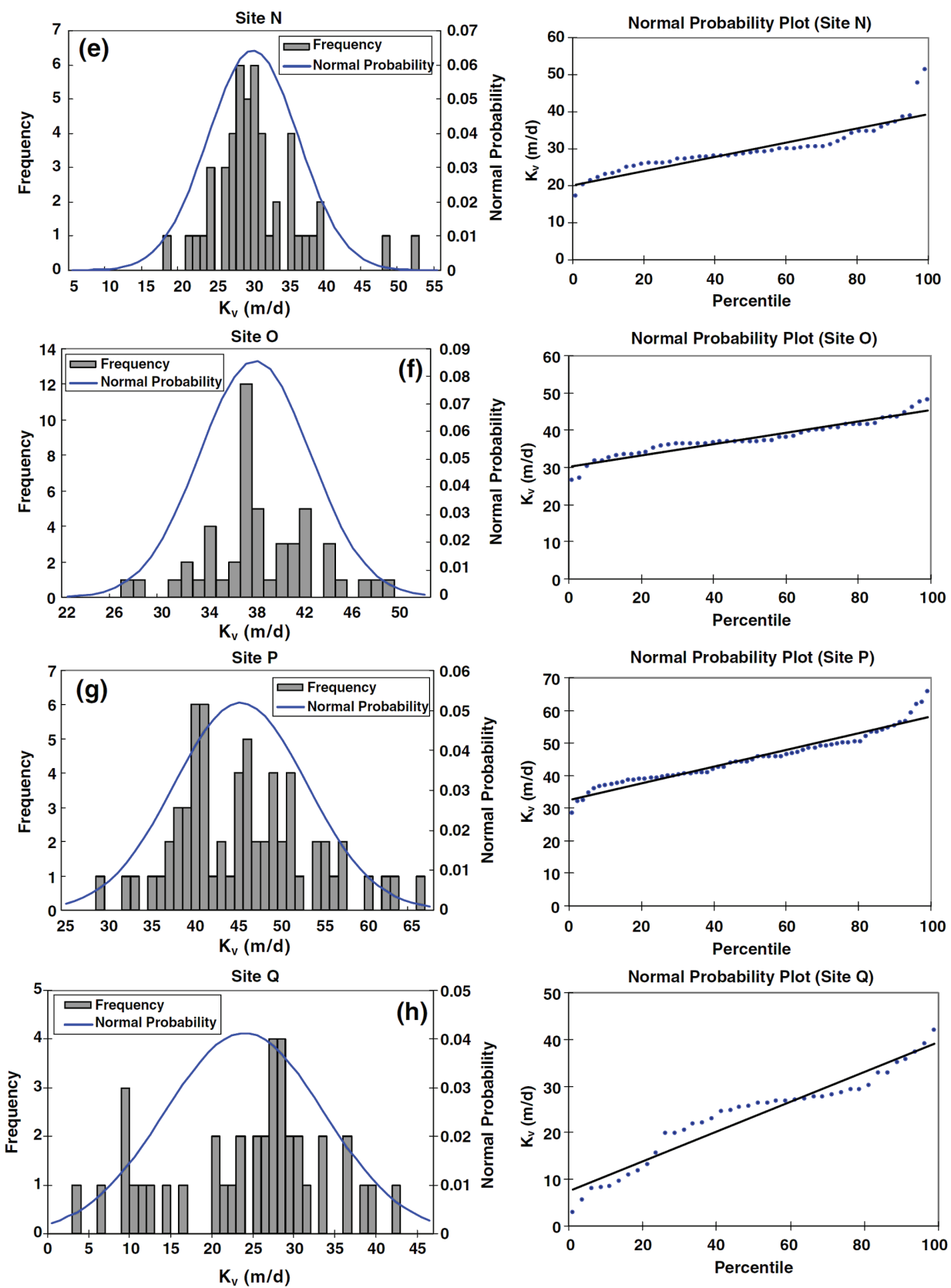

Figure 3. (continued)

ues at both sites $Q$ and R near Ashland were combined as a single dataset, the $88 K_{v}$ values were normally distributed according to all four normality tests (Table 3).

Chen (2005) noted that streambed $K_{v}$ values are normally distributed for the combined dataset at sites A, B, C, D, E, H, and I between Kearney and Central City in the Platte River (Figure 1). In this study, all four normality tests were performed for 


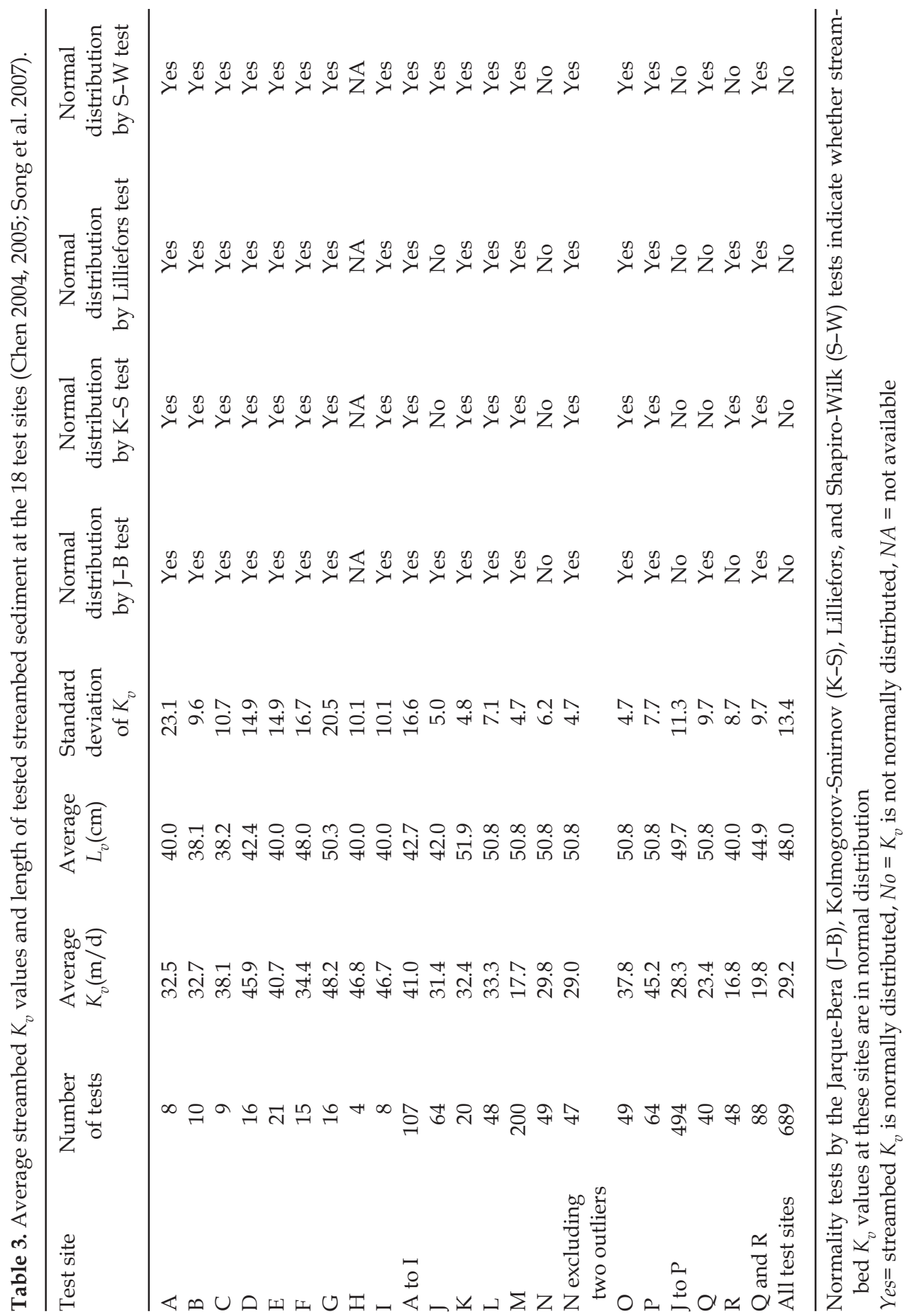


streambed $K_{v}$ values at each of the eight test sites (sites A to I) except for site $\mathrm{H}$, which had only four measurements (Chen 2004, 2005; Song et al. 2007). The results indicated that streambed $K_{v}$ is normally distributed at these individual sites (Table 3). Song et al. (2007) reported the streambed $K_{v}$ values at sites F and G, but they did not perform a statistical distribution analysis of $K_{v}$ values. All four normality tests illustrated that streambed $K_{v}$ values are in normal distribution at sites $F$ and $G$ as well (Table 3). When the $K_{v}$ values obtained from sites $\mathrm{F}$ and $\mathrm{G}$ were combined with those values reported by Chen (2005), the new dataset of streambed $K_{v}$ values from sitesAto I (Chen 2004, 2005; Song et al. 2007; Figure 1) was in normal distribution, which may be attributed to the fact that the Platte River has no tributaries between Kearney and Central City (Figure 1) and thus the streambed sediments within this river reach were well distributed and belonged to a single population of hydraulic conductivity values. $K_{v}$

When all the $K_{v}$ values from sites J to $\mathrm{P}$ were combined, the normality tests indicated that the data are not in normal distribution (Table 3), which may be a result of different hydrogeological processes, including geological conditions, geomorphic history, and physical transport processes (Hoey and Bluck 1999; Rice and Church 1998), controlling the structure of channel sediments at individual sites. Streambed $K_{v}$ was also not normally distributed for the combined data of all the 689 measurements in the Platte River from sites A to R between Kearney and Ashland which was concluded by the four normality tests (Table 3 ).

The experimental semi-variograms of $K_{v}$ and fitting exponential models along the flow direction at the eight new test sites (sites J to Q) in the Platte River are shown in Figure 4 . At site $\mathrm{L}$, the measured semi-variograms of $K_{v}$ increased with the lag distance gradually and the fitted exponential model showed that the values of $\lambda$ (correlation scale) and $C$ (variogram sill value) cannot be determined uniquely when all the semi-variogram values were used. Thus, we chose the first three measured semivariograms of $K_{v}$ to fit an exponential model, and the fitted values of $C$ and $\lambda$ were about 45.2 and $2.1 \mathrm{~m}$, respectively (Figure 4c). At sites K, O, P, and Q, the correlation scale was less than $1.5 \mathrm{~m}$ which corresponds to the distance between the test points. As a result, the streambed $K_{v}$ values along the flow direction at these sites in the Platte River were considered to be independent samples as well as the $K_{v}$ values across the flow direction. However, the correlation scale was larger than the sampling spacing at each of sites J, L, M, and N. The $K_{v}$ values within the correlation scales were taken out and normality tests were performed on the remaining independent sets of streambed $K_{v}$ values. At sites J, L, and $\mathrm{M}$, the correlation scales were less than twice the sample spacing at each site, two independent sets of $K_{v}$ values can be generated after the correlated samples were removed; while at site $\mathrm{N}$, three independent sets of $K_{v}$ values were generated. All the datasets of independent streambed $K_{v}$ values were in normal distribution except for one dataset at site J which was identified by the K-S and Lilliefors tests and one dataset at site $\mathrm{N}$ which was identified by the J-B and S-W tests (Table 4). However, when the largest $K_{v}$ value in this dataset at site $\mathrm{N}$ was regarded as an outlier and taken out, the remaining 13 values are normally distributed determined by all four normality tests. Therefore, the streambed $K_{v}$ values at each of the eight test sites (sites J to Q) between Schuyler and Ashland in the Platte River can be regarded as normally distributed, which indicated that the streambed $K_{v}$ values 

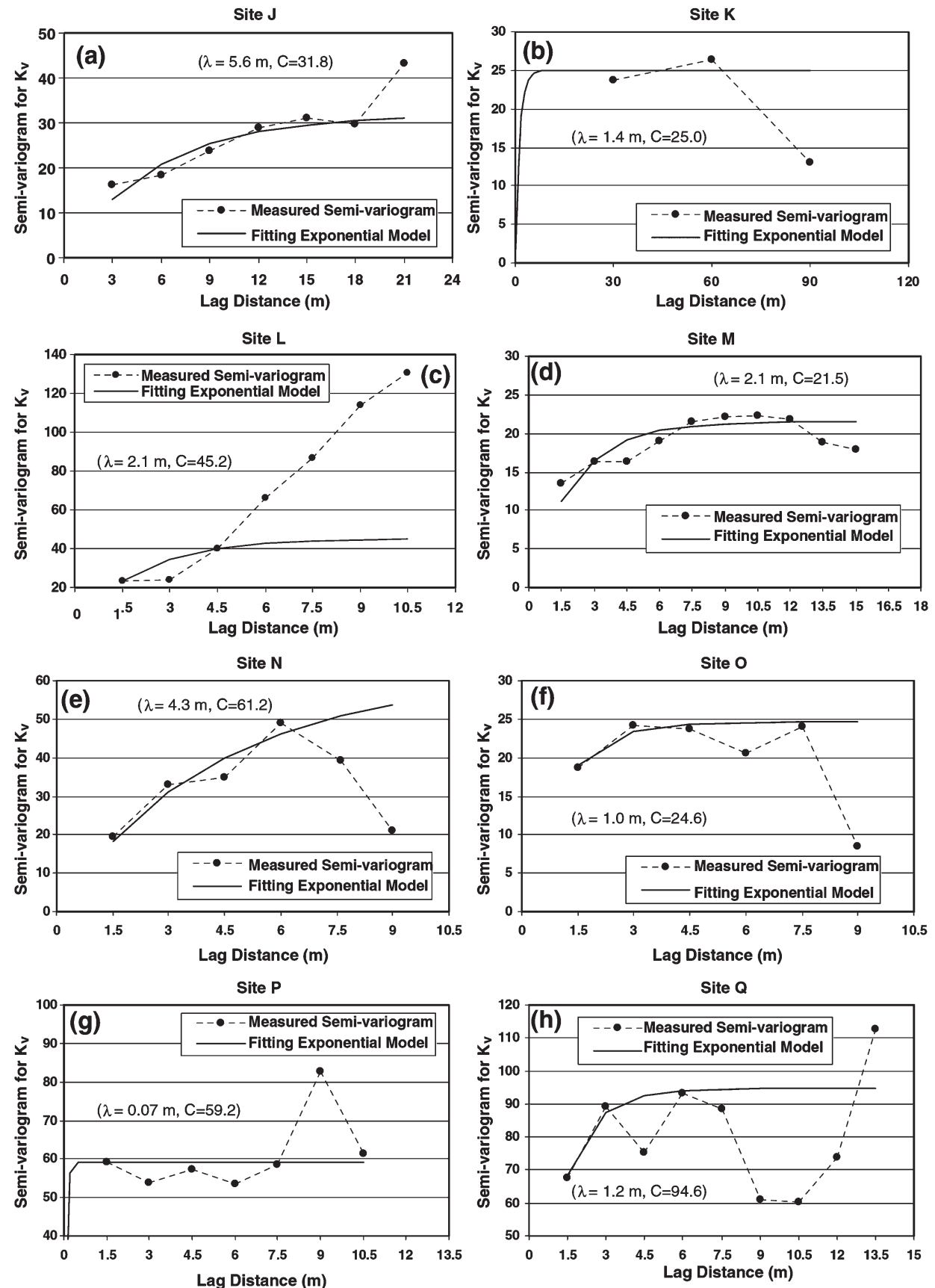

Figure 4. Semi-variogram of $K_{v}$ along the flow direction from sites $\mathrm{J}$ to $\mathrm{Q}$ between Schuyler and Ashland in the Platte River. a site J; $\mathbf{b}$ site K; $\mathbf{c}$ site L; $\mathbf{d}$ site M; e site N; $\mathbf{f}$ site O; $\mathbf{g}$ site P; $\mathbf{h}$ site Q.

cluster around the average $K_{v}$ value and using the average $K_{v}$ value obtained from a large number of measurements to represent the streambed $K_{v}$ characteristics was appropriate at these sites in the Platte River. 


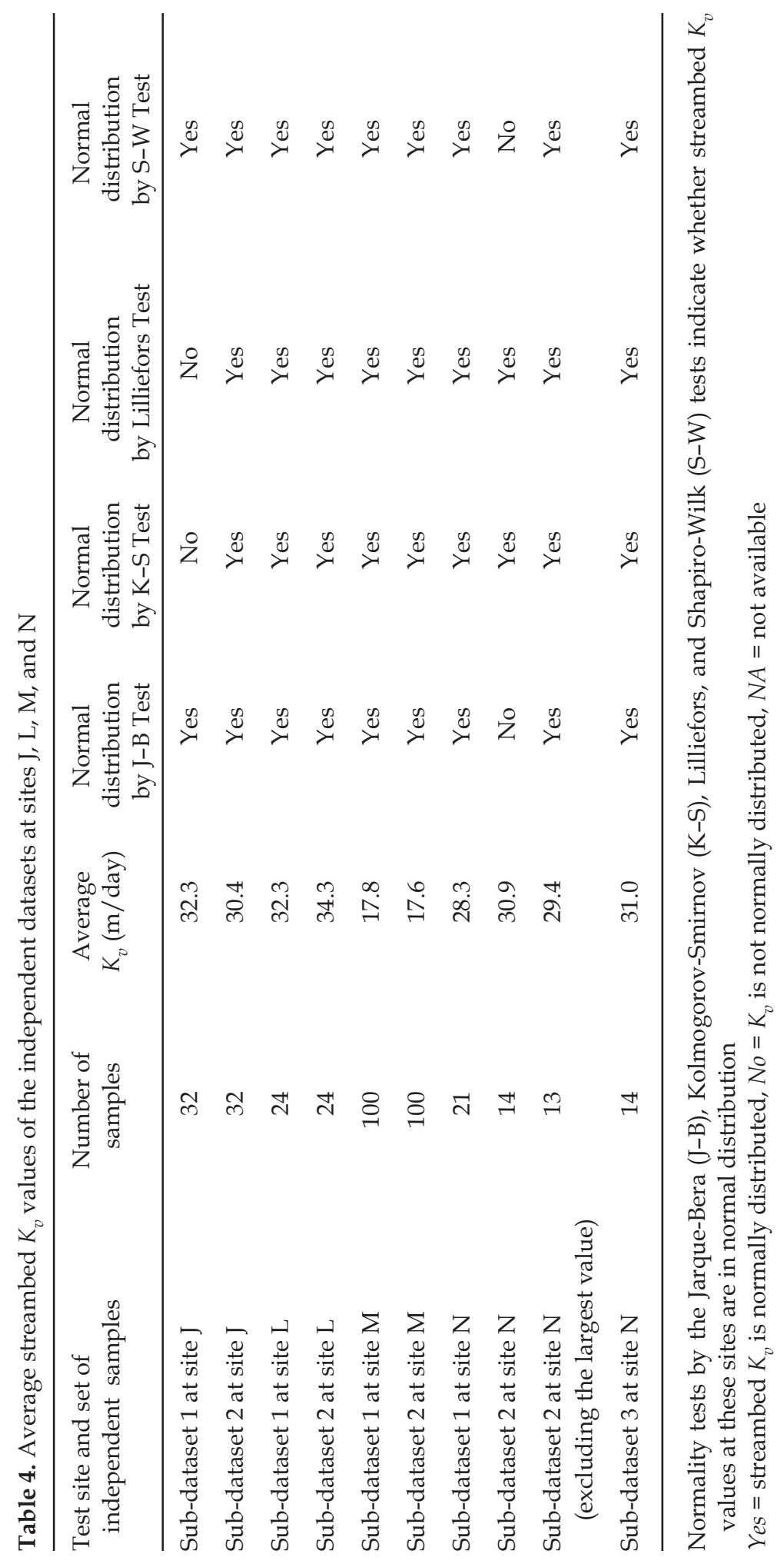



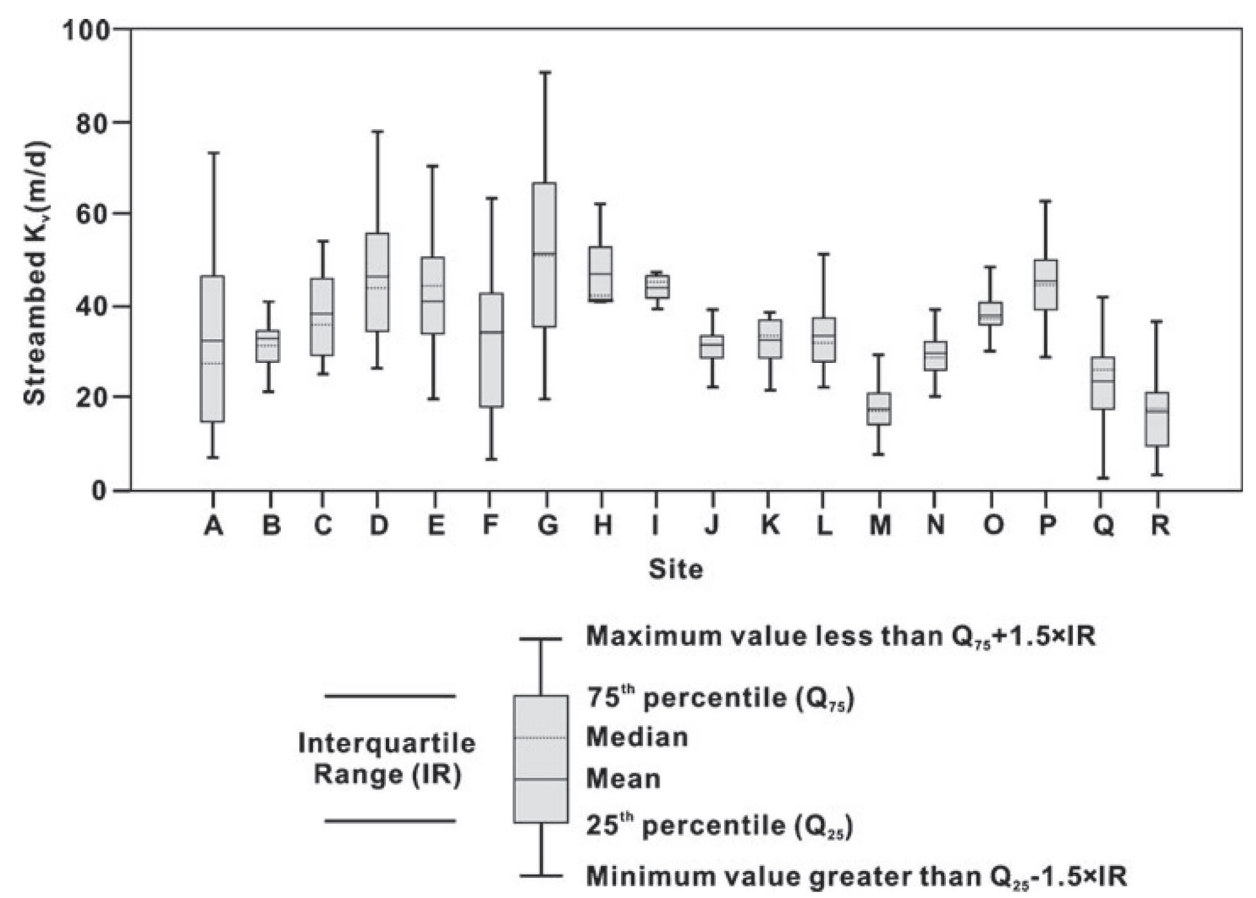

Figure 5. Boxplot of streambed $K_{v}$ values at the 18 test sites (from sites A to R) between Kearney and Ashland in the Platte River in Nebraska (Chen 2004, 2005; Song et al. 2007). Box indicates the upper and lower quartile, the dash horizontal line indicates the median value, and the solid horizontal line indicates the mean value.

\section{Discussion}

5.1 Spatial Variation of Streambed $K_{v}$ Values along the Platte River

At the eight new test sites in this study, the $t$-test suggested that the $K_{v}$ values are similar between sites $\mathrm{J}, \mathrm{K}$, and $\mathrm{L}$ with that all the $p$-values were larger than 0.05 . Site $\mathrm{N}$ also had similar $K_{v}$ values with sites $\mathrm{J}$ and $\mathrm{K}$ but not site $\mathrm{L}$. The $K_{v}$ values at sites $\mathrm{M}$ and $\mathrm{Q}$ were significantly lower than those at all other sites $(p<0.0001)$. Site $\mathrm{M}$ had the lowest average streambed $K_{v}$ value, while the average streambed $K_{v}$ value at site $\mathrm{P}$ was the highest among the eight test sites.

Compared to the average streambed $K_{v}$ values from sites A to I between Kearney and Central City (Figure 1) in the Platte River (Chen 2004, 2005; Song et al. 2007), larger average streambed $K_{v}$ values occurred at sites D, E, G, H, I, and P, which were all greater than $40 \mathrm{~m} /$ day (Figure 5 ). The average streambed $K_{v}$ values at the eight new test sites (sites J to Q) between Schuyler and Ashland in the Platte River were all lower than those between Kearney and Central City, except for sites $\mathrm{O}$ and $\mathrm{P}$, which may be attributed to localized coarse streambed sediments where the permeameter tests were conducted. Nevertheless, the average streambed $K_{v}$ value from sites J to Q in the Platte River was $27.1 \mathrm{~m} /$ day, which was lower than that from sites A to I in the Platte River (41.0 m/ day; Chen 2004, 2005; Song et al. 2007). 


\subsection{Effects of Tributaries on Streambed $K_{v}$ Variability}

Usually the grain size of streambed sediments declines with the distance downstream due to abrasion and sorting, and selective transport (Surian 2002; Frings 2008) and a downstream gravel-sand transition occurs (Singer 2008). Additionally, sediment sources of the tributaries play a significant role in controlling the grain-size pattern change for river bed sediments (Rice 1998). In this study, two other major rivers merge with the Platte River, which can induce additional effects on the distribution of streambed $K_{v}$ values. The Loup River merges with the Platte River near Columbus, which is upstream of site J, while the Elkhorn River merges with the Platte River at where it is only $10 \mathrm{~km}$ upstream of sites $\mathrm{Q}$ and $\mathrm{R}$ near Ashland. The Loup River originates from the Nebraska Sand Hills, which has about $49,695 \mathrm{~km}_{2}$ in drainage. Previous studies hypothesized that the Nebraska Sand Hills is an important factor for the distribution of loess deposits downwind of the Sand Hills. The Sand Hills either serves as a sediment transport pathway and allows loess deposits to be carried away (Mason 2001), or generates silt sized sediments by abrasion and ballistic impacts under strong winds (Muhs 2004). The Loup River thus can carry these fine-grained sediments, which can mix with the sediments moving downstream in the Platte River and result in lower streambed $K_{v}$ values at the eight test sites. At site $Q$ near Ashland, the streambed $K_{v}$ values were lower than those values at other sites in this study and similar results were reported by Chen (2005). Previous research suggests that the Elkhorn River has also lower streambed $K_{v}$ values than the Platte River. First, Huntzinger and Ellis (1993) noted that low-permeability glacialtill deposits occur in the subsurface of the Elkhorn River; and second, Song et al. (2009) found that streambed $K_{v}$ values at the West Point site in the Elkhorn River (about $67 \mathrm{~km}$ upstream of the confluence with the Platte River) were on average 20.7 $\mathrm{m} /$ day. These relatively fine sediments may be carried from the Elkhorn River downstream, and deposited in the Platte River thus resulting in additional damped effects on streambed $K_{v}$ values as well as the Loup River at sites $Q$ and R near Ashland.

\subsection{Streambed $K_{v}$ Variability across the Channel}

Streambed $K_{v}$ values can vary laterally across the river channel. At site $R$, Chen (2005) conducted permeameter tests along four transects on the west half of the Platte River, and he found that the $K_{v}$ values tend to increase towards locations that are further from the river bank. Genereux et al. (2008) also reported that the $K_{v}$ value at the center of the channel is usually higher than the values close to the river bank. In this study, streambed $K_{v}$ values at site $\mathrm{M}$ were much lower than those at site $\mathrm{N}$, given that both sites were located at different sides of the Platte River. However, the nearest measurements were only $3.0 \mathrm{~m}$ to the river bank at site $\mathrm{M}$ and flow velocity was very small here, while site $\mathrm{N}$ was over $50 \mathrm{~m}$ away from the river bank. The center of the river usually has higher flow velocity than the sides of the channel. A larger $K_{v}$ value may occur in the channel sediments where the flow velocity is generally higher, since fine-grained sediments can be washed away by higher flows and they may deposit again in the area with lower flow velocity (Chen 2005). Furthermore, the lowest 
streambed $K_{v}$ values at site $M$ may suggest that the streambed sediments at this site are dominated by the sediments transported from the Loup River; however, a mixture of sediments from the Loup River and Platte River might occur between sites J and $\mathrm{N}$, while the upstream Platte River sediments can be dominant at sites $\mathrm{O}$ and $\mathrm{P}$.

\section{Summary and Conclusions}

In situ permeameter tests were conducted at eighteen test sites between Kearney and Ashland in the Platte River from south-central to eastern Nebraska. The streambed $K_{v}$ values at the eighteen sites (sites A to R) may be categorized into three groups in terms of downstream fining and tributary inputs. The first group was the streambed $K_{v}$ values from site A to I between Kearney and Central City in the Platte River (Chen 2004, 2005; Song et al. 2007). Within this area, the Platte River has no tributaries and the average streambed $K_{v}$ value was $41.0 \mathrm{~m} /$ day. The second group was the streambed $K_{v}$ values from site $\mathrm{J}$ to $\mathrm{P}$ in the Platte River, and the average streambed $K_{v}$ value was $28.3 \mathrm{~m} /$ day within this area. The Loup River merges with the Platte River near Columbus, which is upstream of site J. The Loup River originates from the Nebraska Sand Hills and can carry the fine-grained sediments generated by the Sand Hills to the Platte River. The mixing of the fine-grained sediments from the Loup River and sediments from the downstream Platte River could explain the lower$K$ streambed sediments that occur downstream of the confluence. The third and final group was the streambed $K_{v}$ at sites Q and R (Chen 2005) near Ashland in the Platte River. Another large river, the Elkhorn River, merges with the Platte River at where it is only $10 \mathrm{~km}$ upstream of both the Ashland sites. Low-permeability glacialtill deposits occur in the subsurface of the Elkhorn River (Huntzinger and Ellis 1993), and permeameter tests suggest a lower $K_{v}$ value for streambed sediments in the Elkhorn River (Song et al. 2009), which may contribute additional fine-grained sediments to the Platte River and these lower- $K$ sediments were deposited in the downstream Platte River. The average streambed $K_{v}$ value was $19.8 \mathrm{~m} /$ day for sites $Q$ and $R$ (Chen 2005), which was much lower than those values at other sites, except for site M. Moreover, the streambed sediments at site M might be dominated by the sediments from the Loup River, which resulted in the second-lowest average streambed $K_{v}$ value out of the eighteen test sites. A mixture of sediments from the Loup River and Platte River may occur between sites J and N; however, the streambed sediments at sites $\mathrm{O}$ and $\mathrm{P}$ can be dominated by the upstream Platte River sediments. At sites $\mathrm{Q}$ and R (Chen 2005) near Ashland, a mixture of sediments from the Loup and Elkhorn Rivers and the upstream Platte River can lead to an even lower streambed $K_{v}$ value.

Streambed $K_{v}$ values were normally distributed at nearly each test site in the Platte River from south-central to eastern Nebraska, except for site N. However, when the two largest $K_{v}$ values were regarded as outliers and eliminated from the sample, the remaining streambed $K_{v}$ was in normal distribution at site $\mathrm{N}$. Additionally, when the correlated $K_{v}$ values were removed from the datasets collected from gridded sampling plots, the remaining independent sub-datasets of streambed $K_{v}$ values were still in normal distribution at each of the eight new test sites. The characteristic of normal 
distribution of streambed $K_{v}$ in the Platte River was different from the distribution of $K_{v}$ reported in the West Bear Creek in North Carolina (neither normal nor log-normal) (Genereux et al. 2008), from the log-normal distribution of streambed $K_{v}$ in the Indian Creek in Philadelphia, Pennsylvania reported by Ryan and Boufadel (2007), from the bimodal distribution of streambed $K_{\mathrm{h}}$ in the Colorado River (Springer et al. 1999), and from the log-normal distribution for aquifer materials (Freeze 1975). Moreover, the combined dataset of streambed $K_{v}$ values from site A to I between Kearney and Central City, about $200 \mathrm{~km}$ apart along the Platte River, were normally distributed, which may be due to the fact that the Platte River has no tributaries in-between and thus the streambed sediments were well distributed in the Platte River in this reach and belonged to a single population of hydraulic conductivity values. On the other hand, the combined dataset of streambed $K_{v}$ values from site J to $R$ (Chen 2005) between Schuyler and Ashland, about $100 \mathrm{~km}$ apart along the Platte River, were not in normal distribution. Within this lower reach, the mixture of three sediment sources from the upstream Platte River, the Loup River, and Elkhorn River leads to a wide range of variations in streambed vertical hydraulic conductivity.

Acknowledgments - Funding for the field tests between Schuyler and Ashland was provided by the Lower Platte North Natural Resources District (LPNNRD) of Nebraska. Staff of the LPNNRD helped identified the study sites between Schuyler and Ashland. The land owners on both sides of the Platte River are appreciated for providing the access to the river. The research was also partially supported by the Program for Changjiang Scholars and Innovative Research Team in University of Ministry of Education of China (IRT0811, Utilization and protection of groundwater resource and the environment in arid and semi-arid areas).

\section{References}

Bjerg PL, Hinsby K, Christense TH, Gravesen P (1992) Spatial variability of hydraulic conductivity of an unconfined aquifer determined by a mini slug test. J Hydrol 136:107-122

Cardenas MB, Zlotnik VA (2003) Three-dimensional model of modern channel bend deposits. Water Resour Res 39:1441. doi:10.1029/2002WR001383

Chen XH (2000) Measurement of streambed hydraulic conductivity and its anisotropy. Environ Geol 39(12):1317-1324

Chen XH (2004) Streambed hydraulic conductivity for rivers in south-central Nebraska. J AmWater Resour Assoc 40(3):561-574

Chen XH (2005) Statistical and geostatistical features of streambed hydraulic conductivities in the Platte River, Nebraska. Environ Geol 48(6):693-701

Chen XH (2007) Hydrologic connections of a stream-aquifer-vegetation zone in south-central Platte River valley, Nebraska. J Hydrol 333:554-568. doi: 10.1016/j.jhydrol.2006.09.020

Chen XH, Shu L (2002) Stream-aquifer interactions: Evaluation of depletion volume and residual effects from ground water pumping. Ground Water 40(3):284-290

Chen XH, Burbach M, Cheng C (2008) Electrical and hydraulic vertical variability in channel sediments and its effects on streamflow depletion due to groundwater extraction. J Hydrol 352(3-4):250-266 
Chen XH, Song J, Cheng C, Wang D, Lackey SO (2009) A new method for mapping variability in vertical seepage flux in streambeds. Hydrogeol J 17(3):519-525. doi: 10.1007/ s10040-008-0384-0

Cheng C, Chen XH (2007) Evaluation of methods for determination of hydraulic properties in an aquifer-aquitard system hydrologically connected to a river. Hydrogeol J 15:669-678

Freeze RA (1975) A stochastic-conceptual analysis of one-dimensional groundwater flow in a nonuniform homogeneous media. Water Resour Res 11(5):725-742

Frings RM (2008) Downstream fining in large sand-bed rivers. Earth-Sci Rev 87:39-60

Genereux DP, Leahy S, Mitasova H, Kennedy CD, Corbett DR (2008) Spatial and temporal variability of streambed hydraulic conductivity in West Bear creek, North Carolina, USA. J Hydrol 358:332-353

Goovaerts P (1997) Geostatistics for Natural Resources Evaluation. Oxford University Press, New York, p 483

Goswami D, Kalita PK, Mehnert E (2010) Modeling and simulation of baseflow to drainage ditches during low-flow periods. Water Resour Manag 24:173-191

Hess KM, Wolf SH, Celia MA (1992) Large-scale natural gradient tracer test in sand and gravel, Cape Cod, Massachusetts 3. Hydraulic conductivity variability and calculated macrodispersitivities. Water Resour Res 28(8):2011-2027

Hoey TB, Bluck BJ (1999) Identifying the controls over downstream fining of river gravels. J Sediment Res 69(1):40-50

Huntzinger TL, Ellis MJ (1993) Central Nebraska river basins, Nebraska. J Am Water Resour Assoc 29(4):533-574

Hvorslev MJ (1951) Time lag and soil permeability in ground-water observations. US Army Corps of Engineers, Waterways Experiment Station Bulletin 36:1-50

Kalbus E, Reinstorf F, Schirmer M (2006) Measuring methods for groundwater, surface water and their interactions: A review. Hydrol Earth Syst Sci 10:873-887

Kalbus E, Schmidt C, Molson JW, Reinstorf F, Schirmer M (2009) Influence of aquifer and streambed heterogeneity on the distribution of groundwater discharge. Hydrol Earth Syst Sci 13:69-77

Kelly SE, Murdoch LC (2003) Measuring the hydraulic conductivity of shallow submerged sediments. Ground Water 41(4):431-439

Kennedy CD, Genereux DP, Corbett DR, Mitasova H (2009) Spatial and temporal dynamics of coupled groundwater and nitrogen fluxes through a streambed in an agricultural watershed. Water Resour Res 45:W09401 doi: 10.1029/2008WR007397

Landon MK, Rus DL, Harvey FE (2001) Comparison of instream methods for measuring hydraulic conductivity in sandy streambeds. Ground Water 39(6):870-885

Leek R, Wu JQ, Wang L, Hanrahan TP, Barber ME, Qiu H (2009) Heterogeneous characteristics of streambed saturated hydraulic conductivity of the Touchet River, south eastern Washington, USA. Hydrol Process 23:1236-1246

Mason JA (2001) Transport direction of Peoria loess in Nebraska and implications for loess sources on the central Great Plains. Quat Res 56:79-86

Muhs DR (2004) Mineralogical maturity in dunefields of North America, Africa and Australia. Geomorphology 59:247-269

Rehfeldt KR, Boggs JM, Gelhar LW (1992) Field study of dispersion in a heterogeneous aquifer 3. Geostatistical analysis of hydraulic conductivity. Water Resour Res 28(12):3309-3324 
Rice S (1998) Which tributaries disrupt downstream fining along gravel-bed rivers? Geomorphology 22:39-56

Rice S, Church M (1998) Grain size along two gravel-bed rivers: Statistical variation, spatial pattern and sedimentary links. Earth Surf Processes Landf 23:345-363

Ryan RJ, Boufadel MC (2007) Evaluation of streambed hydraulic conductivity heterogeneity in an urban watershed. Stoch Environ Res Risk Assess 21:309-316

SalehinM, Packman AI, ParadisM(2004) Hyporheic exchange with heterogeneoys streambeds: Laboratory experiments and modeling. Water Resour Res 40:W11504. doi: 10.1029/2003WR002567

Singer MB (2008) Downstream patterns of bed material grain size in a large, lowland alluvial river subject to low sediment supply. Water Resour Res 44:W12202. doi: 10.1029/2008WR007183

Song J, Chen XH, Cheng C, Summerside S, Wen F (2007) Effects of hyporheic processes on streambed vertical hydraulic conductivity in three rivers of Nebraska. Geophys Res Lett 34:L07409. doi: 1029/2007GL029254

Song J, Chen XH, Cheng C, Wang D, Lackey S, Xu Z (2009) Feasibility of grain-size analysis methods for determination of vertical hydraulic conductivity of streambeds. J Hydrol 375(3-4):428-437

Sophocleous MA, Koussis AD, Martin JL, Perkins SP (1995) Evaluation of simplified streamaquifer depletion models for water rights administration. Ground Water 33(4):579-588

Sprent P (2001) Applied nonparametric statistical methods, 3rd edn. Chapman and Hall, London

Springer AE, Petroutson WD, Semmens BA (1999) Spatial and temporal variability of hydraulic conductivity in active reattachment bars of the Colorado River, Grand Canyon. Ground Water 37(3):338-344

Sudicky EA (1986) A natural gradient experiment on solute transport in a sand aquifer: Spatial variability of hydraulic conductivity and its role in the dispersion process. Water Resour Res 22(13):2069-2082

Sun D, Zhan H (2007) Pumping induced depletion from two streams. Adv Water Resour 30: 1016-1026

Surian N (2002) Downstream variation in grain size along an Alpine river: Analysis of controls and processes. Geomorphology 34:137-149

Woodbury AD, Sudicky EA (1991) The geostatistical characteristics of the Borden aquifer. Water Resour Res 27(4):533-546

Zhao P, Shao M, Wang T (2010) Spatial distributions of soil surface-layer saturated hydraulic conductivity and controlling factors on dam farmlands. Water Resour Manag. doi: 10.1007/ s11269-009-9550-y 